\title{
ПРОЕКТИРОВАНИЕ ДЕЯТЕЛЬНОСТИ ОПОРНОГО ВУЗА КАК ИННОВАЦИОННОГО ЦЕНТРА РЕГИОНА
}

\author{
(c) 2019 Фраймович Денис Юрьевич \\ доктор экономических наук, доцент \\ Владимирский государственный университет имени Александра Григорьевича \\ и Николая Григорьевича Столетовых, Россия, Владимир \\ E-mail:fdu78@rambler.ru
}

В статье актуализируется вопрос о приоритетности инновационного пути в развитии экономики РФ. Одним из механизмов которого является модель опорного вуза региона, который определяется как инновационный центр региона. Выделяется миссия, задачи и цели опорного вуза.

Ключевые слова: Инновации, инновационный потенциал, опорный вуз, регион, система высшего образования.

Система высшего образования, в настоящий момент, прошла основные трансформационные этапы и представляет собой сложную систему, характеризующую наличием множества вузов, с разными типами задач (Рисунок 1).

Федеральные университеты. Тип российских вузов, созданный на базе нескольких вузов, представляющий из себя крупный научный и образовательный центр федерального округа. Основная задача аккумулировать научные и образовательные ресурсы в рамках нескольких регионов, быть точкой роста и притяжения федерального округа. На данный момент в РФ создано 10 таких вузов.

Национально-исследовательские университеты. Тип российских вузов, основной задачей который является развитие научных исследований. На данный момент создано 29 таких вузов.

Вузы проекта 5-100. Тип российских вузов, основной задачей которых является активизация научной и образовательной деятельности. Цель вузов проекта войти в число 100 ведущих вузов мира (по основным рейтингам). На дан- ный момент создан 21 такой вуз.

Опорные университеты. Тип российских вузов, основная задача которых стать центром социально-экономического развития региона. На данный момент создано 33 опорных вуза.

Современная экономика - это модель экономики знаний, действующая в условиях быстрого развития научно-технического прогресса. Тема инновационного развития занимает важное место в российской экономике: создаются новые институты развития (Сколтех, Иннополис, Роснано), принята программа стратегия инновационного развития РФ, определены “майские указы” Президента РФ и национальные проекты, где важное значение уделяется активизации инновационных процессов.

В комплексе мер это привело к позитивной динамике основных показателей инновационной деятельности (Таблица 1).

B рамках рейтинга Bloomberg Innovation Index 2019 Россия сегодня входит в топ-30 инновационных экономик мира. Однако, для страны, обладающим большим научным, человеческим и инновационным потенциалом необходимо

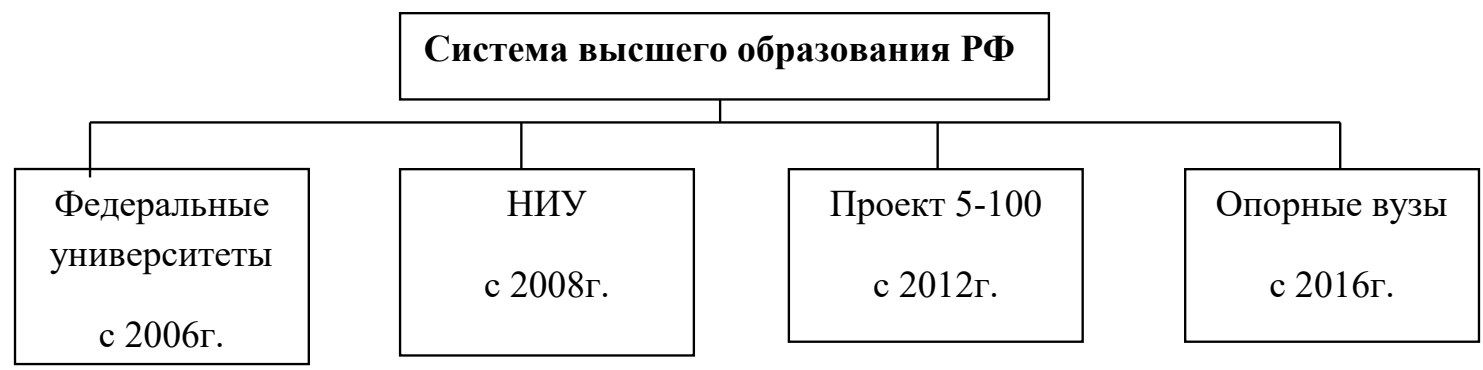

Рисунок 1. Система высшего образования РФ 
Таблица 1. Рейтинг инновационных экономик 2019: Bloomberg Innovation Index 2019[4]

\begin{tabular}{|c|l|c|c|c|c|c|c|c|c|}
\hline № & Страна & Очки & $\begin{array}{c}\text { Интен- } \\
\text { сивность } \\
\text { исследо- } \\
\text { ваний и } \\
\text { разрабо- } \\
\text { ток }\end{array}$ & $\begin{array}{c}\text { Произ- } \\
\text { водство } \\
\text { нобавлен- } \\
\text { мости- }\end{array}$ & $\begin{array}{c}\text { Продук- } \\
\text { тивность }\end{array}$ & $\begin{array}{c}\text { Плотность } \\
\text { высоких } \\
\text { техноло- } \\
\text { гий }\end{array}$ & $\begin{array}{c}\text { Эфек- } \\
\text { тивность } \\
\text { образово- } \\
\text { ния }\end{array}$ & $\begin{array}{c}\text { Концен- } \\
\text { трация } \\
\text { исследо- } \\
\text { ваний } \\
\text { Патент- } \\
\text { ная ак- } \\
\text { тивность }\end{array}$ \\
\hline 1 & Южная Корея & 87.3 & 2 & 2 & 18 & 4 & 7 & 7 & 20 \\
\hline 2 & Германия & 87.3 & 7 & 3 & 24 & 3 & 14 & 11 & 7 \\
\hline 3 & Финляндия & 85.5 & 9 & 16 & 5 & 13 & 9 & 8 & 5 \\
\hline 4 & Швейцария & 85.4 & 3 & 4 & 7 & 8 & 13 & 3 & 27 \\
\hline 5 & Израиль & 84.7 & 1 & 33 & 8 & 5 & 36 & 2 & 4 \\
\hline 6 & Сингапур & 84.4 & 13 & 5 & 11 & 17 & 1 & 13 & 14 \\
\hline 7 & Швеция & 84.1 & 4 & 15 & 9 & 6 & 20 & 5 & 25 \\
\hline 8 & США & 83.2 & 10 & 25 & 6 & 1 & 43 & 28 & 1 \\
\hline 9 & Япония & 81.9 & 5 & 7 & 22 & 10 & 39 & 18 & 10 \\
\hline 10 & Франция & 81.6 & 12 & 41 & 13 & 2 & 11 & 20 & 15 \\
\hline 27 & Россия & 66.8 & 33 & 37 & 51 & 25 & 10 & 24 & 30 \\
\hline
\end{tabular}

ставить амбициозные цели, войти в топ-10 инновационных экономик мира. По мнению автора, именно 10-15 стран, являющиеся в ближайшие 3-5 лет мировыми инновационными лидерами будут определять мировой экономический контур в ближайшие 50-70 лет.

Для достижения таких амбициозный целей российская экономическая модель должна сделать активизацию инновационных процессов основной парадигмой развития всех процессов, при этом драйверами будут являться вузы, которые во многом формируют инновационный ландшафт, а также кадры, научный и инновационный потенциал.

Фактически мы наблюдаем, что в топ-500 мировых вузов представлено порядка 10 российских вузов, а в топ-100 - 1 российский вуз. Анализируя место российских вузов в мировом масштабе (Таблица 2) мы приходим к мнению, что несмотря на позитивную динамику рейтингов, необходимо более активно развивать механизмы инновационного развития, международного сотрудничества, публикационной активности, показателя который во многом формирует научный потенциал.

Последним этапом модернизации российской системы высшего образования являются опорные вузы. Сегодня опорные вузы это 33 вуза, в 32 субъектах Российской Федерации. В планах Министерства науки и высшего образования увеличить число опорных вузов до 80 .

При этом мы наблюдаем российскую специфику формирования ВВП. По итогам 2017 г. 70\% ВВП РФ формируются в регионах (без учета гг. Москва, Санкт-Петербург и Московской области). Таким образом, от формирования эффективной региональной экономической модели, во многом, зависит, уровень экономического

Таблица 2. Российские вузы в международных рейтингах, 2019[5], [6]

\begin{tabular}{|c|c|c|}
\hline ВУЗ & ARWU-рейтинг & QS-рейтинг \\
\hline МГУ & 87 & 90 \\
\hline СПбГУ & $301-400$ & 235 \\
\hline МФТИ & $401-500$ & 312 \\
\hline НГУ & $401-500$ & 244 \\
\hline УрФУ & $601-700$ & 412 \\
\hline ИТМО & $801-900$ & $511-520$ \\
\hline КФУ & $801-900$ & 439 \\
\hline МИСИС & $801-900$ & 476 \\
\hline ТГУ & $801-900$ & 277 \\
\hline ГУ-ВШЭ & $901-1000$ & 343 \\
\hline
\end{tabular}


Таблица 3. Рейтинг инновационной активности регионов, АИРР[1]

\begin{tabular}{|c|l|c|}
\hline № Регион & Наличие опорного вуза \\
\hline 1 & г. Санкт-Петербург & нет \\
\hline 2 & Татарстан & нет \\
\hline 3 & г. Москва & нет \\
\hline 4 & Томская область & нет \\
\hline 5 & Московская область & нат \\
\hline 6 & Новосибирская область & нет \\
\hline 7 & Калужская область & да \\
\hline 8 & Нижегородская область & да \\
\hline 9 & Ульяновская область & да \\
\hline 10 & Самарская область & да \\
\hline 11 & Тюменская область & да \\
\hline 12 & Башкортостан & нет \\
\hline 13 & Мордовия & нет \\
\hline 14 & Свердловская область & Да \\
\hline 15 & Тульская область & \\
\hline
\end{tabular}

развития страны.

В связи с тем, что в условиях экономики знаний определяющим фактором становится развитие инновационной деятельности, автор предлагает строить региональную экономическую модели на базе развития инновационного потенциала опорного вуза, который фиксируется, как инновационный региональный центр.

Также отметим, что уже на данный момент из топ-15 инновационных регионов России в 7 регионах представлены опорные вузы, что позволяет говорить о базисе инновационного развития для опорных вузов (Таблица 3).

Концепция миссии опорного университета должна базироваться на базисе социальноэкономического развития региона. Например, миссия Владимирского государственного университета как опорного вуза Владимирской области - комплексное содействие опережающему развитию Владимирской области путем обеспечения экономики региона высококвалифицированными кадрами, прорывными научно-исследовательскими и инновационными разработками, повышения активности молодежи в социокультурной среде и, в целом, повышения конкурентоспособности научнообразовательной среды Владимирской области на национальном и международном уровнях [3].

Основными задачами опорного вуза явля- ются:

- создание эффективной модели трансфера технологий в регионе;

- развитие социальных программ в регионе;

- конкурентная борьба за абитуриентов;

- развитие человеческого капитала в регионе;

Целевая модель развития опорного вуза предполагает:

- инициация по созданию институтов инновационного развития в регионе;

- развитие предпринимательских компетенций в региональной системе высшего образования;

- формирование региональной инновационной экосистемы;

- использование современных методов в образовательной и научной деятельности (онлайн-образование, коллаборация и т.д.).

Автор согласен с мнением [2], что не следует ограничивать деятельность опорного вуза границами региона. Опорный вуз должен выступать как центр притяжения для пограничных регионов.

Создание модели развития региона на базе опорного вуза позволит превратить региональные экономические системы в устойчивую и конкурентную систему, способствующую инновационному развития региона и страны. 


\section{Библиографический список}

1. Ассоциация инновационных регионов России[Электронный ресурс]. - Режим доступа: http://i-regions.org.

2. Иванов С.А., Сокол-Номоконов Э.Н. Феномен опорных университетов региональной экономики в современной России // Высшее образование в России. 2018. № 1 (219). С. 19-30.

3. Программа развития ВлГУ [Электронный ресурс].- Режим доступа: http://www.vlsu.ru/index.php?id=1625.

4. Рейтинг инновационных экономик - 2019 [Электронный ресурс].- Режим доступа: https://theworldonly. org/rejting-innovatsionnyh-ekonomik-2019.

5. Рейтинг ARWU [Электронный ресурс].- Режим доступа: http://www.shanghairanking.com/ARWU2019.html.

6. Рейтинг QS [Электронный ресурс].- Режим доступа: https://www.topuniversities.com/qs-world-universityrankings. 